\title{
IAMJ
}

INTERNATIONAL

AYURVEDIC

MEDICAL JOURNAL

ISSN: 2320-5091

Impact Factor: 6.719

\section{MEDICINAL PROPERTIES OF MUSTAKA IN AYURVEDA: A COMPREHENSIVE REVIEW}

\section{Neha Prajapati ${ }^{1}$, Amit Mishra², Mita Kotecha ${ }^{3}$}

${ }^{1}$ Asst. Professor, Dept. of Dravyaguna, Vijyashree Ayurvedic Medical College \& Hospital, Jabalpur, Madhya Pradesh, India

${ }^{2}$ Asst. Professor, Dept. of Rasashastra and Bhaishajya Kalpana, Vijyashree Ayurvedic Medical College \& Hospital, Jabalpur, Madhya Pradesh, India

${ }^{3}$ Professor and H.O.D., Dept. of Dravyaguna, National Intitute of Ayurveda, Jaipur, Rajasthan, India

Corresponding Author: neha11790.prajapati@gmail.com

\section{https://doi.org/10.46607/iamj1209072021}

(Published Online: July 2021)

Open Access

(C) International Ayurvedic Medical Journal, India 2021

Article Received: 08/06/2021 - Peer Reviewed: 13/06/2021 - Accepted for Publication: 18/06/2021

\section{Check for updates}

\begin{abstract}
Ayurveda medicine exists on the planet for the benefit of humanity. Ayurveda's value is in its ability to maintain individual health and treat a patient's condition. Following the daily routine, seasonal regimen, codes for healthy behaviour, ethical regimen, and so on, one can obtain good health. Plants are the foundation of Ayurveda, an ancient Indian system of holistic treatment. Mustaka (Cyperus rotundus Linn) is described as 'Kyambu' in the Vedic literature, its synonyms like 'Gundra \& Gangeyam' denotes the hydrophytic nature of this plant. Mustaka can be used to treat a variety of ailments. It is a significant herbal medication that may be utilised in a variety of ways to treat a variety of illnesses, mostly in the Kapha-Pitta dosha. Acharya Charaka has emphasised that each substance on the earth is useful in combating illness when applied with planning and for a specific purpose.
\end{abstract}

Keywords: Ayurveda, Mustaka, Kyambu, Kapha, Pitta. 


\section{INTRODUCTION}

Musta is mentioned in the Vedas and other Vedic writings. The Atharva parisista grantha, Varaha srotasutra, and Hiranyakesi srota sutra all mention it. ${ }^{1}$ In the Atharvveda Parishishta, Mustak is mentioned among Usheer, Tagara, Kushtha, and Sarshapa. Here it has been told that God is also hypnotised by fumigation of these drugs in powdered form. ${ }^{2}$ Musta is also known as Gangeya, which means it is thought to be the image of Ganga, Gundra, which means it grows near water, Sugandhi, which means it has a pleasant odour, Vaarid, which means it grows near water, and Hima, which means it reduces the effects of burning and heating. ${ }^{3}$ Musta is used in many simple and compound drug preparations to treat various ailments since time immemorial. Musta is having a variety of dosage forms used internally as well as externally. Musta can be applied externally in the form of Taila and Ghrita (medicated vegetable oil and animal fat), Lepa (Topical application), Pradeha (Thick or Viscid ointment), and Upanaha (Thick or Viscid ointment), and Upanaha (Poultice), Pragharsha (Rubbing), Parisheka (Drug Sprinkling/Showering), and Dhupana (Fumigation) formulations are available. Musta can also be used internally in various forms such as Kashaya (Decoction), Churna (Powder), Swarasa (fresh juice), Guti/Vati (Pills), Varti (Suppository), Kalka (Paste form), Lavana (Salt preparation), Kshara (Alkali form) and administered in various Karmas such as Vasti (Enema), Nasya ((Nasal drop), Gandusha (Gargling), Anjana (Collyrium). It can be used as a food item in the form of Pramathya (dough prepared by boiling medicinal substances) and Paniya. ${ }^{4}$ Mustak and Nagarmustka are important drugs of Ayurveda. Mustaka and Nagarmustaka have a wide therapeutic range because they are employed in a variety of traditional formulations for the treatment of various ailments. Mustaka (Cyperus rotundus Linn.) is an erect and perennial glabrous herb with a woody subterranean stoloniferous rhizome which is clothed with fibrous remains of leaf sheaths. Stems are nodose at the base, 3-gonous and 10-60 $\mathrm{cm}^{\text {high. }}{ }^{5}$
TAXONOMICAL CLASSIFICATION OF MUS$T A K A^{6}$

Taxonomic Classification of Mustak

Kingdom - Plantae

Division - Phanerogams

Subdivision - Angiosperms

Class - Monocotyledonae

Series - Glumaceae

Order - Glumiflorae

Family - Cyperaceae

Sub Family - Scirpoideae

Genus - Cyperus

Species - Cyperus rotundus

Botanical Name - Cyperus rotundus (Linn.)

VERNACULAR NAMES ${ }^{7}$

English - Nut Grass/Purple nutsedge, Hindi - Nagarmotha \& Motha, Bengali - Mutha, Gujarati - Moth, Nagar Moth, Tamil - Korai, Muthakach, Telugu Tungmuste, Tungmustalu, Arabic - Sohed Kufi, Rajasthani - Motha

\section{BOTANICAL DESCRIPTION ${ }^{8}$}

Habit \& Habitat- Perennial herb 10-75 cm height, perennating using a creeping sympodial rhizome, growing in damp, boggy or marshy habitat.

Stem- At base nodosely thickened and suddenly constricted into a wiry rhizome, subsolitary, triquetrous at top.

Leaves- Long, often overtopping stem.

Flowers- In compound umbel, spikes loosely spicate of 3-8 spikelets.

Seed- Trigonous nuts.

\section{FLOWERING AND FRUITING PERIOD-}

July- August and November-December

\section{DISTRIBUTION ${ }^{\mathbf{9}}$}

It has a worldwide range but is mostly found in the Northern and Southern hemisphere's Sub-arctic and temperate zones. It can be found all over India, up to an elevation of 1800 metres, from Kashmir to Shimla, Garhwal and Khasia hills in practically all states, and ascending the Central Tablelands ranges from Mount Abu and Pune to the Nilgiri highlands. 


\section{COLLECTION PERIOD-}

September- October

CHEMICAL CONSTITUENTS ${ }^{10}$ -

Cyperen $1 \& 2$, eplerenone, isopatchoulenone, cyperotundone, cyperol, cyperolone, isocyperol, isoko- busone, kobusone, mustakone, patchulene, sugenol etc.

\section{SUBSTITUTES \& ADULTRANTS ${ }^{11}$}

Cyperus scariosus (R. Br.) and Cyperus arundinaceum (Baker) are used as substitutes to Cyperus rotundus.

Table 1: CATEGORIZATION OF MUSTAKA IN AYURVEDA CLASSICS:

\begin{tabular}{|c|c|c|}
\hline S. No. & Classical texts & Gana and Varga \\
\hline 1. & Charak Samhita & Lekhaniya,${ }^{12}$ Trishnanigrahana,${ }^{13}$ Kandughna,${ }^{14}$ Stanyasodhana ${ }^{15}$ \\
\hline 2. & Sushruta Samhita & Mustadi, ${ }^{16}$ Vachadi Gana ${ }^{17}$ \\
\hline 3. & Astang Sangraha & Mustadi, ${ }^{18}$ Vachadi Gana ${ }^{19}$ \\
\hline 4. & Dhanvantri Nighantu & Guduchaiyadi Varga ${ }^{20}$ \\
\hline 5. & Madanpal Nighantu & Abhyadi Varga ${ }^{21}$ \\
\hline 6. & Kaidev Nighantu & Aushadhi Varga 22 \\
\hline 7. & Bhavaparkasha Nighantu & Karpuradi Varga ${ }^{23}$ \\
\hline 8. & Priya Nighantu & Satpushpaadi Varga ${ }^{24}$ \\
\hline
\end{tabular}

\section{AYURVEDIC PROPERTIES}

\section{Pharmacodynamics (Rasa Panchaka) ${ }^{25}$}

- Rasa - Tikta, Katu, Kashaya

- Guna - Laghu, Ruksha

- Veerya-Sheeta

- Vipaka-Katu

Doshakarma, Kapha-Pitta Shamak

Part used, Rhizome

Dose: Churna (Powder) 3-6 gm, Kwatha (Decoction $50-100 \mathrm{ml}$ )

\section{TYPES OF MUSTAK IN CLASSICAL TEXTS}

Brihatrayi, has only mentioned the Mustaka and there is no description of Nagarmustaka. Description of Nagarmustaka is mainly found in different nighantu. Nighantu created so much confusion regarding the identity of Mustaka and Nagarmustaka. Some considered both as synonyms and some described both as varieties.

- Dhanwantari nighantu ${ }^{26}$, Bhavprakash nighantu, ${ }^{27}$ Raj nighantu ${ }^{28}$ and Shaligram nighantu $^{29}$ considered Mustaka and Nagarmustaka as varieties.

- Sodhala ${ }^{30}$ and Madanpal nighantu ${ }^{31}$ considered as synonyms.
- Priya nighantu ${ }^{32}$ had only mentioned the Mustaka and there is no description about Nagarmustaka in this nighantu.

Botanical sources of Three types of Mustak are described as under ${ }^{33}$ -

1. Mustak (Bhadra Mustak) - Cyperus rotundus Linn. (Nut Grass)

2. Nagar Mustak-Cyperus scariosus Linn.

3. Jal Mustak-Cyperus esculentus

\section{CLASSICAL REFERENCES ${ }^{34}$}

Fever-

- Water boiled with Musta, parpata, usira, chandana, balak and sunthi and cooled should be given to pacify thirst and fever.

- Parpata mixed with musta or sunthi or duralabha should be given in form of decoction or cold infusion.

- Musta and parpata are excellent remedies for fever.

\section{Diarrhoea-}

- Decoction of musta alone should be taken mixed with honey.

- Musta rhizomes (twenty in number) should be boiled in milk with three times more water reduced to milk. Its intake checks mucus and pain. 
- The patient should be given to drink water processed with vacha and prativisha or musta and parpata or haridra and sunthi.

- Mustaka is crushed and boiled in equal milk reduced to one-fourth. When cooled it is mixed with honey and taken. It checks diarrhoea with mucus and blood.

Halimaka- Lauha-bhasma mixed with musta powder should be taken with a decoction of khadira in the case of halimaka.

Vatarakta-

- In vatarakta predominant in kapha, decoction of musta, draksha and haridra mixed with honey should be taken. Similarly, that of triphala or Guduchi is useful.

- Decoction of musta, amalaka and haridra should be taken with honey, it alleviates vatarakta associated with kapha.

Alcoholic- Water boiled with musta digest the pathos. It should be used in all types of alcoholism.

Loose teeth- Mustaka is the main drug in mustadi vati useful in the disease.

Cough- Sarkaradi formulation should be given mixed with musta and marica in cough caused by pitta associated with kapha.

Vomiting- To control vomiting caused by kapha, powder of sour badara mixed with jambu seeds; karkatasringi, mixed with musta or duralabha and mixed with honey should be taken.

Thirst- Thirst as a complication of visuchika, water processed with bhadramusta should be given.

Accidental wound- One root of Musta pounded finely with cow ghee is applied as a paste on the wound.

Eye disease- Bhadramusta rubbed with goat's urine is applied as collyrium. It destroys chronic corneal opacity and redness.

\section{PHARMACOLOGICAL ACTIONS}

The tubers are acrid, bitter, astringent, cooling, antiinflammatory, revulsive, galactagogue, depurative, intellect promoting, nervine tonic, digestive, carminative, stomachic, anthelmintic, dieuretic, expectorant, febrifuge, antiperiodic and tonic. They are useful in hyperdipsia, flatulence, colic, vomiting, intestinal worms, diarrhoea, and dysentery, vomiting inflammations, fevers, intermittent and malarial fever.

\section{PROPAGATION AND CULTIVATION ${ }^{35}$}

It is a perennial weed, thrives on all kinds of soil under varying climatic conditions. Regeneration is mainly through underground rhizomes. Greenhouse observations show that a new tuber is formed in about 3 weeks after an isolated tuber is planted and 146 tubers and basal bulbs are produced from a single tuber in $31 / 2$ months.

\section{PHARMACOLOGICAL STUDIES}

Anti-Inflammatory activity-The alcoholic extract of Mustak Possessed anti-inflammatory activity against carrageenan induced oedema and also found effective against formaldehyde induced arthritis in albino rats. ${ }^{36}$

Anti-Pyretic activity-The alcoholic extract of Mustak showed highly significant antipyretic activity against pyrexia produced in albino rats by subcutaneous injection of a suspension of dried Brewer's yeast in gum acacia in normal saline. ${ }^{37}$

Analgesic activity- The petroleum ether extract and essential oil of C.rotundus are reported to possess analgesic activity. ${ }^{38}$

Tranquillizing activity- The ethanolic extract of $C$. rotundus reduced the spontaneous motor activity, potentiated the pentobarbital narcosis and deranged the motor coordination abolished the conditioned avoidance response in the animal. ${ }^{39}$

Anti-convulsion activity- Pre-treatment with ethanolic extract of C.rotundus caused significant protection against strychnine and leptazol-induced convulsions in mice. ${ }^{40}$

Anti-emetic activity- The ethanolic extract of $C$. rotundus in the dose of $128.1 \pm 11.6 \mathrm{mg} / \mathrm{kg}$ was found to protect $50 \%$ of dogs against apomorphine-induced vomiting. ${ }^{41}$

Inhibition of gastric motility activity- Decoctions of Rhizome Cyperus rotundus were given orally to rats for $30 \mathrm{~min}$. The findings in this study suggest that the protective action of $C$. rotundus Linn. is related to its inhibition of gastric motility and endogenous prostaglandins may play an important role. Zhu M, et al 1997 
Anti-diarrhoeal Activity- The methanol extract of Cyperus rotundus rhizome, given orally at the doses of 250 and $500 \mathrm{mg} / \mathrm{kg}$ showed significant antidiarrhoeal activity in castor oil-induced diarrhoea in mice. (Uddin S.J. et al 2006)

\section{CONCLUSION}

Musta's botanical source has been identified as Cyperus rotundus Linn. In Charak Samhita agreya dravya sangraha, Acharya Charak said that Musta is best among those Sangrahik, appetizers and digestives. According to Ashtang Hriday, Musta is best for Jwara because of its Tikta, Katu rasa, it has Amapachak properties, making it useful in Jwara and Amatisara. In Charak samhita Mustak is classified in Lekhaneeya mahakashaya by virtue it has medoghna activity. Due to Tikta and Katu rasa it gets rid of altered Jatharagni and Medodhatvagni. Due to Laghu, Ruksha guna alleviates Meda and Kapha shoshana action. Because of its Kashaya rasa, it's utilised to heal loose teeth. Musta is also beneficial in Stanyavikriti, Kasa, Halimaka, Trishna, Vatarakta, Madatyaya and other practises. It is also an especially useful plant from a modern standpoint because its variation Cyperus esculentus Linn includes various nutrients such as energy (starch, fat, sugar, and protein), dietary minerals, palmitic acid, stearic acid, oleic acid, linoleic acid, and fatty acids.

\section{REFERENCES}

1. Sharma P. V. Dravyaguna Vignana (Vol-4: Vedic Plants and History of Dravyaguna). Reprint. Varanasi; Chaukhambha Bharati Academy; 2007. p.119.)

2. Atharvaveda parishishta35/2/9-11

3. Sharma P.V., Namarupagyanam (Characterization of Medicinal Plants), Chaukhambha Visvabharati, Varanasi, 1 st edition, 2001.

4. Sharma P.C, Yelne M.B, Dennis T.J. Database on medicinal plants used in Ayurveda and Siddha. Vol. 3. New Delhi; CCRAS, Dept. of AYUSH; Ministry of Health and Family Welfare; Govt. of India; 2005. p. 405-406.)

5. Dr Anil K. Dhiman, Medicinal Plants of Uttaranchal state, Chowkhamba Sanskrit series office, Varanasi, P. 446-63.

6. https://en.wikipedia.org/wiki/Cyperus_rotundus
7. Acharya Priyavrat Sharma, Dravyaguna Vigyan, volume II, Reprint edition 2012, Chaukhamba Visvabharati, Adhyay 5, p-370.

8. Dr. J.L.N. Sastry, Dravyaguna vijnana, Vol.2, Chaukhambha Orientalia, Varanasi, Reprint edition 2017, p.no. 551-557.

9. Ibdem (4)

10. Ibdem (5)

11. Ibdem (4)

12. Agnivesh, Charaka, Dradhabala, Charaka Samhita, Sutrasathana, edited with Vidyotini Hindi commentary by Pt. Kashinath Sastri, Reprint edition 2013, Chaukhamba Bharati Academy, Varanasi, Adhaya 4/3, p72.

13. Agnivesh, Charaka, Dradhabala, Charaka Samhita, Sutrasathana, edited with Vidyotini Hindi commentary by Pt. Kashinath Sastri, Reprint edition 2013, Chaukhamba Bharati Academy, Varanasi, Adhaya 4/3, p72.

14. Agnivesh, Charaka, Dradhabala, Charaka Samhita, Sutrasathana, edited with Vidyotini Hindi commentary by Pt. Kashinath Sastri, Reprint edition 2013, Chaukhamba Bharati Academy, Varanasi, Adhaya 4/29, p87.

15. Agnivesh, Charaka, Dradhabala, Charaka Samhita, Sutrasathana, edited with Vidyotini Hindi commentary by Pt. Kashinath Sastri, Reprint edition 2013, Chaukhamba Bharati Academy, Varanasi, Adhaya 4/18, p84.

16. Sushruta, Sushruta Samhita, Sutrasathana, Edited with Ayurveda-Tattava-Sandipika, commentary by Kaviraj Dr Ambika Dutt Shastri, Reprint edition 2012; Chaukhamba Sanskrit sansthan, Varanasi, Chapter38/69, p.no.187.

17. Sushruta, Sushruta Samhita, Sutrasathana, Edited with Ayurveda-Tattava-Sandipika, commentary by Kaviraj Dr Ambika Dutt Shastri, Reprint edition 2012; Chaukhambha Sanskrit Sansthana, Varanasi; Adhaya 38/69; p-185.

18. Vriddha Vagbhatta, Astang Sangraha, Sutrasathana, Edited with Saroj Hindi commentary by Dr Ravi Dutt Tripathi, Chaukhamba Sanskrit Pratisthana, Delhi, Adhaya 16/34, p-329.

19. Vriddha Vagbhatta, Astang Sangraha, Sutrasathana, Edited with Saroj Hindi commentary by Dr Ravi Dutt Tripathi, Chaukhamba Sanskrit Pratisthana, Delhi, Adhaya 16/34, p-319.

20. Mahendra Bhogik, Dhavantri Nighantu, Guduchiyadi Varga, edited by Prof. Priyavrat Sharma, Chaukhambha Orientalia, Varanasi, p-23.

21. Acharya Madanapala, Madanapala Nighantu, edited by Pandit Hariharprasad Trivedi, Chaukhambha Krishnadas, Academy Varanasi,2009.

22. Kaidev, Kaidev Nighantu, Aushadha Varga, edited and translated by Acharya Priyavart Sharma and Dr 
Guru Prasad Sharma, Chaukhambha Orientalia, Varanasi, p-252.

23. Bhavmishra, Bhavprakash Nighantu, Karpuradi Varga, commentary by Dr K.C. Chunekar, edited by Dr G.S. Pandey, Reprint edition 2013, Chaukhambha Bharati Academy, Varanasi, p-233.

24. Acharya Priyavart Sharma, Priya Nighantu, Satpushpadi Varga, by Acharya Priyavart Sharma, 2 nd edition 1995, Chaukhambha Surbharati Prakashan, Varanasi, p-82.

25. Sharma PV, Dravyaguna Vijnana, Vol.2. Reprint ed. Varanasi: Chaukhamba Bharati Academy; 2015.

26. Prof. Priya Vrat Sharma, Translated by Dr Guruprasad Sharma, Danwantari nighantu, $4^{\text {th }}$ Edition, Chaukhamba Orientalia, Varanasi, 2005; p.no.23.

27. Bhavprakash nighantu of Shri Bhavmishra, commentary by Prof. K.C. Chunekar, edited by Late Dr G.S Pandey, Chaukhamba Bharati Academy, Varanasi, Reprint 2013; p. No. 234.

28. Rajnighantu of Pandit Narhari, By Dr Indradeo Tripathi, Chaukhamba Krishnadas Academy, p.no. 163.

29. Shaligramvaishya, Shaligrm nighantu Bhushanam i.e. Brihat Nighanturatnakar antargat Part 7-8, Bombay-4, Khemraj Shrikrishnadas Prakashan, January 2011; p.no.55-56.

30. Prof. Gyanendra Pandey, Edited by Prof. R.R. Dwivedi, Forward by Prof. M.S. Baghel, Sodhala Nighantu, Chaukhamba Krishnadas Academy, 2009; p.no. 27.

31. Prof. Gyanendra Pandey, Madanpal Nighantu, $1^{\text {st }}$ Edition, Chaukhamba Orientalia, Varanasi, 2012, p.no.136.

32. Prof. Priya Vrat Sharma, Priya Nighantu, $2^{\text {nd }}$ Edition, Chaukhmba Surbharati Prakashan, Varanasi, 1995, p.no.82.

33. Dr J.L.N Shastry, Dravyaguna Vijnana, volume II, forwarded to Prof. K.C. Chunekar, reprint edition 2015, Chaukhamba Orientalia, Varanasi, p-552-553.

34. Sharma Priyavrat, Classical uses of Medicinal plants, Chaukhambha Visvabharati Varanasi, the reprint year 2018, P.no 308-10.

35. Ibdem (4)

36. Sundaram, M.S. \& Sivakumar, T. \& Balamurugan, G. (2008). Anti-inflammatory effect of Cyperus rotundus Linn. leaves on acute and subacute inflammation in experimental rat models. Biomedicine. 28. 302-304.

37. Gupta MB, Palit TK, Singh N, Bhargava KP. Pharmacological studies to isolate the active constituents from Cyperus rotundus possessing anti-inflammatory, antipyretic and analgesic activities. Indian J Med Res. 1971 Jan;59(1):76-82. PMID: 5574385.

38. Biradar, Sandeep \& Kangralkar, V.A. \& Mandavkar, Y. \& Thakur, Megha \& Chougule, N. (2010). Antiinflammatory, antiarthritic, analgesic and anticonvulsant activity of Cyperus essential oils. International
Journal of Pharmacy and Pharmaceutical Sciences. 2. 112-115.

39. Singh N, Kulshrestha V K, Gupta M B and Bhargava $\mathrm{K}$ P, Pharmacological studies on Cyperus rotundus, Indian J Pharma, 1969, 1(2), 9.

40. Swamy, Shivakumar \& Hiremath, Suresh \& Hallikeri, C.s \& Hatapakki, B.C. \& Handiganur, J.S. \& Sankh, Kuber \& Shivakumar, B. (2009). Anticonvulsant Effect of Cyperus rotundus Linn Rhizomes in Rats. Journal of Natural Remedies. 9. 192-196. $10.18311 / \mathrm{Jnr} / 2009 / 239$.

41. Singh N, Kulshrestha V K, Gupta M B and Bhargava K P, A Pharmacological study of Cyperus rotundus, Indian J Med. Res, 1970, 58, 103-109.

\section{Source of Support: Nil \\ Conflict of Interest: None Declared}

How to cite this URL: Neha Prajapati et al: Medicinal Properties Of Mustaka In Ayurveda: A Comprehensive Review. International Ayurvedic Medical Journal \{online\} 2021 \{cited July 2021\} Available from: http://www.iamj.in/posts/images/upload/1398_1403.pdf 